\title{
Assessment of overweight and obesity in Iranian adolescents: optimal cut-off values of anthropometric indices
}

\author{
Mohammad Motlagh, ${ }^{1}$ Seiyed Shirvani, ${ }^{2}$ Zahra Hassanzadeh-Rostami, ${ }^{3}$ Majzobeh Taheri ${ }^{4}$ and Reza Ghadimi ${ }^{2}$
}

'Ahvaz Jundishapur University of Medical Sciences, Ahvaz, Islamic Republic of Iran (Correspondence to: Mohammad E. Motlagh: motlagh@health. gov.ir). ${ }^{2}$ Social Determinants of Health Research Center, Health Research Institute, Babol University of Medical Sciences, Babol, Islamic Republic of Iran. ${ }^{3}$ Department of Community Nutrition, Nutrition and Food Sciences Research Center, School of Nutrition and Food Sciences, Shiraz University of Medical Sciences, Shiraz, Islamic Republic of Iran. ${ }^{4}$ Department of Health, Ministry of Health and Medical Education, Tehran, Islamic Republic of Iran.

\begin{abstract}
Background: Various indices have been used to estimate overweight and obesity; all have limitations and strengths. The prevalence of overweight and obesity may differ by ethnicity.

Aims: This study evaluated waist circumference (WC), waist-to-hip ratio (WHpR), waist-to-height ratio (WHtR) and neck circumference $(\mathrm{NC})$ as reliable alternatives to body mass index for screening for overweight and obesity, and determined their optimum cut-off values in different ethnic groups.

Methods: The study was conducted from November 2015 to February 2016 among adolescents aged 12-14 years from five ethnicities in the Islamic Republic of Iran: Arab, Kurdish, Sistani and Baluchi, Turkish and Turkman. Stratified multistage sampling was used to select 2444 students. Receiver operating characteristic curves were constructed to evaluate WC, WHpR, WHtR and NC as screening indices for overweight and obesity as categorized by body mass index centiles.

Results: The prevalence of overweight and obesity in the total sample were $15.3 \%$ and $9.2 \%$ respectively, with higher rates in students of Arab, Kurdish and Turkish ethnicity. The areas under curve ranged from 0.8 to 0.9 for WC, WHtR and NC. The mean optimum values with the highest sensitivity and specificity to identify overweight were: $72.3 \mathrm{~cm}$ (sensitivity 0.80 , specificity 0.75$)$ for WC, $0.46(0.85,0.70)$ for WHtR and $31 \mathrm{~cm}(0.76,0.76)$ for NC. For obesity mean optimum values were: $77 \mathrm{~cm}(0.84,0.81)$ for WC, $0.50(0.84,0.84)$ for WHtR and $31.5 \mathrm{~cm}(0.88,0.71)$ for NC.
\end{abstract}

Conclusions: WC, WHtR and NC may be useful tools to screen for adiposity using their optimum values for sex and ethnicity.

Keywords: overweight, obesity, anthropometric indices, adolescent, ethnicity, Iran

Citation: Motlagh ME; Shirvani SDN; Hassanzadeh-Rostami Z; Taheri M; Ghadimi R. Assessment of overweight and obesity in Iranian adolescents: optimal cut-off values of anthropometric indices. East Mediterr Health J. 2018;24(10):975-987. https://doi.org/10.26719/2018.24.10.975

Received: 09/01/17; accepted: 03/07/17

Copyright (C) World Health Organization (WHO) 2018. Some rights reserved. This work is available under the CC BY-NC-SA 3.o IGO license (https:// creativecommons.org/licenses/by-nc-sa/3.o/igo).

\section{Introduction}

The increasing trend of overweight and obesity is a critical public health problem worldwide (1). Obesity in children and adolescents increases the risk of metabolic syndrome conditions. Furthermore, it can cause chronic disease in adulthood, such as hyperlipidaemia, diabetes, metabolic syndrome, muscle-skeletal disorders, asthma and apnoea (2). Fat distribution and type of obesity are the main predictors of metabolic disorders (3). Despite the serious health risks of obesity in all age groups, no exact index to determine body fat percentage is available (4). Various indices have been used to estimate overweight and obesity with varying limitations and strengths. However, body mass index (BMI) is the most appropriate method for screening of weight status in all age groups (5).

Two popular indices for abdominal obesity are waist circumference (WC) and waist-to-hip ratio (WHpR) (6). Waist-to-height ratio (WHtR) is another index to estimate waist girth. WHtR adjusted for height is a new predictor of obesity and cardio/metabolic risks (7). In addition, neck circumference (NC) has recently been used as a new measure of fat deposition and cardio/metabolic disease $(8-10)$. Studies have shown that abdominal obesity better predicts major causes of death-cancer and cardiovascular disease-compared with BMI $(11,12)$. Similarly, NC can accurately predict metabolic syndrome and blood pressure differences as it measures upper body adiposity (13). Therefore, the limitations of BMI in detecting fat distribution and differentiating between fat and muscle deposition can be overcome using WC and NC.

Anthropometric indices are affected by demographic factors such as age, sex, race or ethnicity, and geographical location because of different characteristics of populations in body size and composition (14). Thus, the cut-off points of these indices differ in various regions. Consequently, the levels of obesity and obesityrelated health risks may differ by ethnicity at the same level of BMI. For instance, health risks at lower levels of BMI among Asian populations have been reported (15).

This study aimed to evaluate the use of $\mathrm{WC}, \mathrm{WHpR}$, $\mathrm{WHtR}$ and $\mathrm{NC}$ as a reliable alternative to BMI and determine the optimal cut-off values for identification of overweight and obesity. 


\section{Methods}

\section{Study design and sample}

This community-based cross-sectional survey was carried out from November 2015 to February 2016. The sample included adolescents aged 12-14 years from 5 different ethnic groups in 5 geographical regions of the Islamic Republic of Iran where each ethnic group is concentrated. The study participants were categorized into the following 5 ethnic groups according to both their parents' ethnicity and their place of residence.

- Arab ethnicity: inhabitants in some parts of Khozestan province

- Kurdish: mostly from western Islamic Republic of Iran (Kurdistan province)

- Sistani and Baluchi: ethnic group in Sistan and Bluchestan province in the east of the country

- Turkish ethnicity: mostly living in the north-east of the country, especially in Azerbaijan, Ardabil and Zanjan provinces

- Turkman: a branch of Turkmen in northern and north-eastern Islamic Republic of Iran (Golestan and Khorasan provinces).

The sample size was estimated as 504 for each ethnic group based on $30 \%$ predicted prevalence of obesity (16), $95 \%$ confidence interval and a precision level of $5 \%$ (total of 2520 ). The participants were selected using stratified multistage sampling according to socioeconomic status and geographical location. In the first stage, 125 junior high schools (25 schools from each ethnic region) were selected by random sampling, out of a total of 674 schools in all 5 provinces. Then, 20 adolescents were selected in each school by simple random sampling (Figure 1). After drop-outs, the final sample was 2444 students.

Inclusion criteria were students between 12 and 14 years of age from the selected ethnicities. Exclusion criteria were other ethnic origins and students with developmental and intellectual disabilities, which was assessed by asking the student's teacher.

Verbal consent was obtained from all participants and their parents or legal caregivers after explaining the aim of the study.

\section{Data collection}

Demographic variables and anthropometric measures were obtained for all participants, including age, sex, ethnicity, residence area, weight, height, waist circumference, hip circumference and neck circumference.

Weight and height measures were taken by trained health staff. Weight was recorded in light clothing by a digital weighing scale (Beurer, Germany) to the nearest $0.1 \mathrm{~kg}$. Weight scale accuracy was checked against standard scales, twice a day. Height was measured barefoot using a non-stretch tape measure (Seca, Japan) to the nearest $0.5 \mathrm{~cm}$. WC was measured at the midway between the lowest rib margin and the iliac crest while the student was standing, and hip circumference was measured at the maximum extension of the buttock using a non-stretch measuring tape, to the nearest $0.1 \mathrm{~cm}$. $\mathrm{NC}$ was measured at the midway of the neck, between mid-cervical spine and mid anterior neck using a nonstretch measuring tape, to the nearest $0.1 \mathrm{~cm}$.

WHpR was the ratio of the waist to hip circumferences and WHtR was calculated by dividing the waist circumference by height. BMI was calculated as weight divided by height squared $\left(\mathrm{kg} / \mathrm{m}^{2}\right)$. The students were categorized as underweight (BMI lower than 5th age- and sex- specific centiles), normal weight (BMI between 5 th and 85th age- and sex-specific centiles), overweight (BMI between 85th and 95th age- and sex-specific centiles), and obese (BMI greater than 95th age- and sex-specific centiles) based on NCHS/CDC cut-off points (17).

\section{Data analysis}

Statistical analyses were performed using SPSS, version 18. Anthropometric indices and demographic characteristics of the participants were reported as mean and standard deviation (SD) and frequency. Normal distribution of the data was checked using histogram and Q-Q plots. We assessed between-group comparisons using the independent samples t-test and one-way ANOVA; post-hoc tests were used for further analysis.

Receiver operating characteristic (ROC) curves were used to determine the usefulness of WC, WHpR, WHtR and NC as screening tools of overweight and obesity, and to estimate appropriate cut-off values by the Youden index. The area under the curve (AUC) and 95\% confidence interval (CI) were calculated from the ROC analysis to determine the overall accuracy of the anthropometric indices in screening for overweight and obesity.

Sensitivity and specificity values, and true-positive and true-negative rates were calculated to construct the ROC curves. Sensitivity was defined as the probability that obesity or overweight would correctly classify subjects who were test-positive for each method (WC, WHpR, WHtR and NC). Specificity was defined as the probability of correctly classifying the subjects who were test-negative for each method (WC, WHpR, WHtR and $\mathrm{NC})$.

A P-values less than 0.05 was considered statistically significant.

\section{Ethical considerations}

The study was approved by the Ethics Committee of Ahvaz Jundishapur University of Medical Science, Ahvaz, Islamic Republic of Iran.

\section{Results}

A total of 2444 students, aged 12-14 years, participated in the study, $48 \%$ of whom were boys. Demographic characteristics and anthropometric data of the students according to sex and ethnic group are summarized in Table 1. Girls had a significantly higher mean BMI than boys ( $P$ $<0.001)$. There were significant differences between the ethnic groups in relation to all anthropometric indices $(P<0.001)$. Mean BMI was significantly higher in stu- 


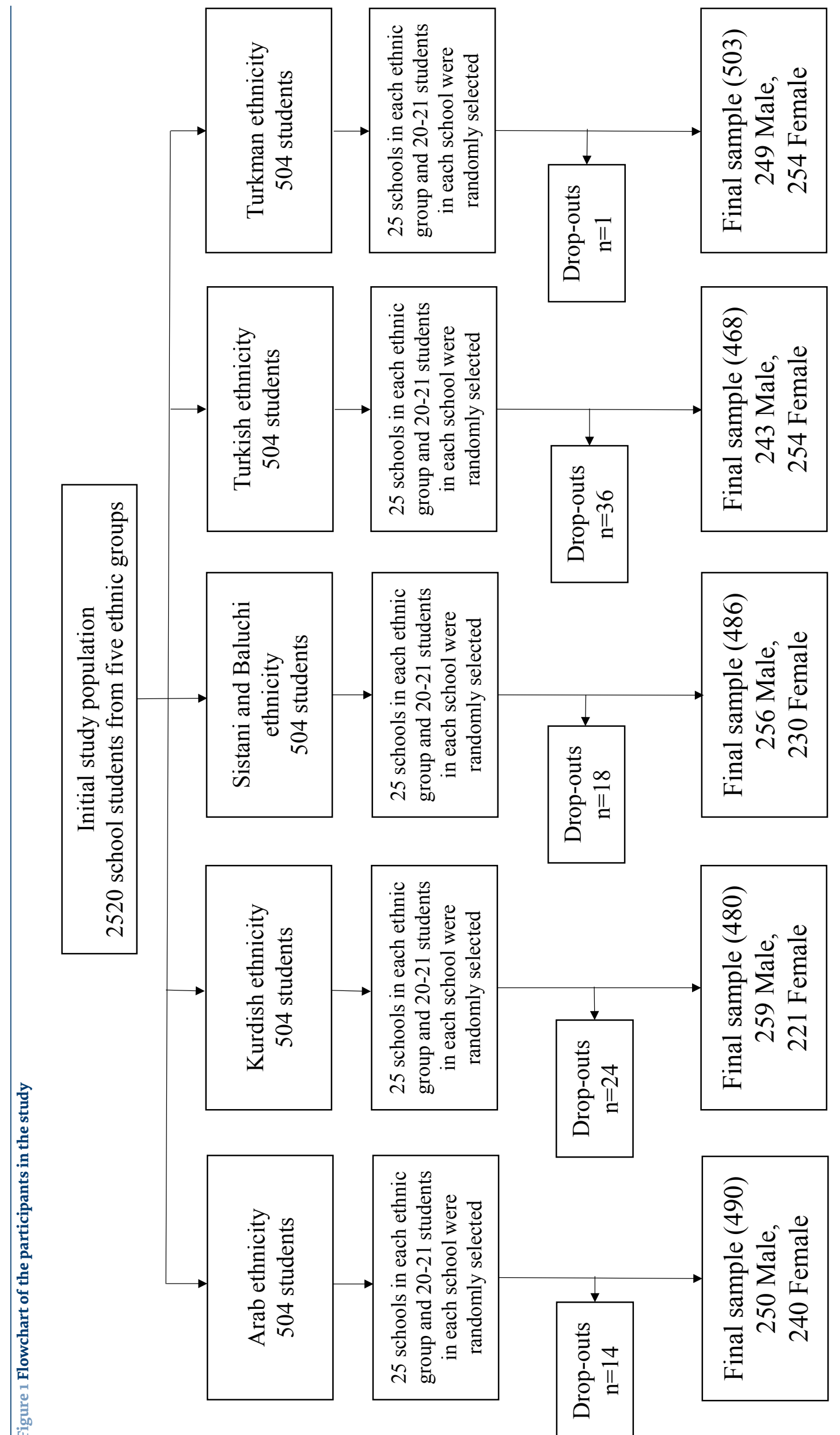




\begin{tabular}{|c|c|c|c|c|c|c|}
\hline Characteristic & Age (years) & BMI $\left(\mathbf{k g} / \mathrm{m}^{2}\right)$ & WC & WHpR & WHtR & NC \\
\hline \multicolumn{7}{|l|}{ Ethnicity } \\
\hline Arab & $13.05(0.7)$ & $20.91(4.57)^{\mathrm{a}}$ & $70.98(10.22)$ & $0.82(0.06)$ & $0.45(0.06)$ & $29.87(2.93)^{d}$ \\
\hline Kurdish & $12.94(0.69)$ & $19.95(3.86)$ & $78.02(10.38)$ & $0.89(0.04)^{c}$ & $0.49(0.06)^{c}$ & $31.51(2.41)^{\mathrm{e}}$ \\
\hline Sistani \& Baluchi & $13.07(0.69)$ & $17.98(3.46)^{b}$ & $68.64(8.47)$ & $0.83(0.07)$ & $0.44(0.04)$ & $29.89(2.59)^{\mathrm{f}}$ \\
\hline Turkish & $12.89(0.72)$ & $20.03(3.56)$ & $69.99(12.26)$ & $0.82(0.07)$ & $0.44(0.07)$ & $31.56(2.80)^{g}$ \\
\hline Turkman & 13.06 (0.69) & $19.85(3.59)$ & 71.98 (10.09) & $0.83(0.06)$ & $0.45(0.06)$ & $30.89(2.52)$ \\
\hline$P$-value (one-way ANOVA) & $<0.001$ & $<0.001$ & $<0.001$ & $<0.001$ & $<0.001$ & $<0.001$ \\
\hline \multicolumn{7}{|l|}{ Sex } \\
\hline Male & $12.99(0.68)$ & $19.22(3.84)$ & $71.24(10.29)$ & $0.85(0.60)$ & $0.45(0.06)$ & $30.71(2.79)$ \\
\hline Female & $13.01(0.72)$ & $20.23(3.98)$ & $71.77(11.41)$ & $0.83(0.07)$ & $0.46(0.07)$ & $30.85(2.73)$ \\
\hline $\begin{array}{l}P \text {-value (independent } \\
\text { samples t-test) }\end{array}$ & 0.39 & $<0.001$ & 0.23 & $<0.001$ & 0.24 & 0.75 \\
\hline
\end{tabular}

Data are presented as mean (standard deviation).

Multiple comparisons were done using post-hoc tests which showed statistically significant differences between the ethnic groups: aArab ethnicity compared to other ethnic groups; bSistani \& Baluchi ethnicity compared to other ethnic groups; cKurdish ethnicity compared to other ethnic groups; dArab ethnicity compared to other ethnic groups except Sistani \& Baluchi ethnicity; eKurdish ethnicity compared to other ethnic groups except Turkish ethnicity; fSistani \& Baluchi ethnicity compared to other ethnic groups except Arab ethnicity; gTurkish ethnicity compared to other ethnic groups except Kurdish ethnicity.

$\mathrm{BMI}=$ body mass index; $\mathrm{WC}=$ waist circumference; $\mathrm{WHpR}=$ waist-to-hip ratio; $\mathrm{WHtR}=$ waist-to-height ratio; $\mathrm{NC}=$ neck circumference.

dents of Arab ethnicity and lower in Sistani and Baluchi students compared to other groups. Students of Kurdish ethnicity had significantly higher WC, WHpR and WHtR values compared to other ethnic groups. NC was significantly higher in Kurdish and Turkish students, and lower in Arab, and Sistani and Baluchi students.

The prevalence of underweight, overweight and obesity in the total sample was $6.7 \%, 15.3 \%$ and $9.2 \%$ respectively using BMI centiles. Table 2 shows the prevalence of underweight, overweight and obesity according to sex and ethnicity. The lowest prevalence of both overweight (8.8\%) and obesity (3.1\%) was seen in Sistani and Baluchi students. The highest prevalence of overweight was seen in female Kurdish students $(21.6 \%)$ and male Turkish students $(21.8 \%)$. The highest prevalence of obesity was seen in both girls and boys of Arab ethnicity.

Table 3 shows the relationship between anthropometric indices and underweight, overweight and obesity (as categorized by BMI). A significant increasing trend was seen in all anthropometric indices with increasing BMI score.

The AUC of anthropometric indices assuming BMI overweight and obesity categories as standard criteria are shown in Table 4. The AUC of WC, WHtR and NC showed very good accuracy to identify overweight and obesity, as indicated by AUCs greater than 0.8. The AUC of WHpR showed sufficient accuracy, as indicated by AUCs greater than 0.6 (Table 4 and Figure 2).

Tables 5 and 6 show the optimal cut-off points to identify overweight and obesity, as determined by the highest sensitivity and specificity, according to sex and ethnic group. In the total male population, the optimal cut-off values of WC to identify overweight and obesity were respectively $72.75 \mathrm{~cm}$ and $77.55 \mathrm{~cm}$; WHpR were
0.88 and 0.88 ; WHtR were 0.46 and 0.49 , and NC were $30.95 \mathrm{~cm}$ and $31.55 \mathrm{~cm}$. These values in females to identify overweight and obesity were respectively: WC: $72.75 \mathrm{~cm}$ and $77.70 \mathrm{~cm}$; WHpR: 0.84 and 0.84; WHtR: 0.47 and 0.50; and NC: $30.9 \mathrm{~cm}$ and $31.60 \mathrm{~cm}$.

\section{Discussion}

Our findings indicate that $15.3 \%$ of the participants were overweight and $9.2 \%$ were obese. The anthropometric indices WC, WHtR and NC identified overweight and obesity accurately, as categorized by BMI centiles. Furthermore, the optimum values of WC, WHtR and NC were $72.3 \mathrm{~cm}, 0.46$ and $31 \mathrm{~cm}$ respectively to identify overweight, and $77 \mathrm{~cm}, 0.50$ and $31.5 \mathrm{~cm}$ respectively to identify obesity, based on the maximum sensitivities and specificities.

Recent studies have reported similar though slightly lower rates of overweight and obesity in Iranian schoolaged children (18-23). This may be a consequence of the nutrition transition that is occurring in developing countries (24). In our study, students of Arab ethnicity had the highest BMI values and those of Sistani and Baluchi ethnicity had the lowest. Moreover, we observed a higher prevalence of obesity in students of Arab ethnicity compared with other ethnic groups. The main causes of higher obesity in Arab ethnicity may be different dietary habits, inactivity due to the hotter and more humid climate conditions in Khozestan and genetic factors (25). On the other hand, the prevalence of overweight and obesity were lowest in the Sistani and Baluchi ethnic group and a high prevalence of underweight was observed in this group. In this regard, Mirmohammadi et al. also reported low prevalence rates of overweight and obesity in Baluchi ethnic groups (20). The lower socioeconomic development in this region and lower availability of food might be the reason. Our study found that girls had 


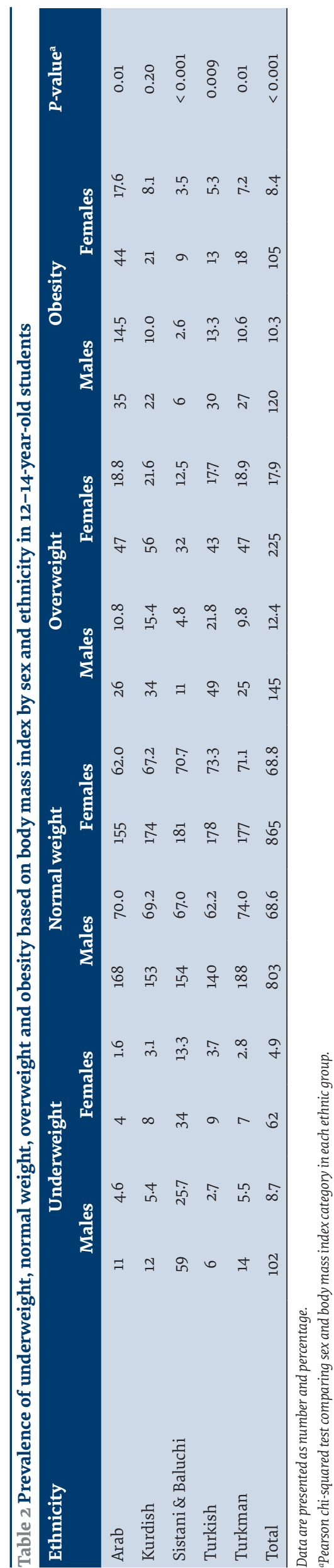

significantly higher BMI values than boys. The higher BMI in girls may be due to less physical activity, as was shown in the CASPIAN study conducted in the Iranian population (23). In addition, we found boys had a higher prevalence of obesity and lower prevalence of overweight than girls. Other studies have reported similar results $(18,26,27)$. However, different results have been reported by other studies. For instance, 2 studies in Iranian children and/or adolescents reported a higher prevalence of both overweight and obesity in boys $(19,28)$. These differences may be due to differences in mean age of the participants and residence.

The second part of our study demonstrated the suitability of WC, WHpR, WHtR and NC to screen for overweight and obesity, as an alternative to BMI centiles. The BMI index does not determine fat content and distribution in overweight individuals which is a limitation, particularly as central fat and upper adiposity are reliable indicators of cardio/metabolic disorders $(13,14)$.

A higher AUC for WHtR was found compared to WC, NC, and WHpR. This concurs with previous studies that showed a higher AUC for WHtR compared to WC to screen for obesity (29-31). Moreover, WHtR was a good predictor of body fat percentage and, in particular, it was more sensitive than BMI in identifying body fat, measured by skinfold methods $(32,33)$. Furthermore, a systematic review and meta-analysis reported WHtR was a stronger predictor of cardiovascular disease risk factors compared with WC in different age and ethnic groups (34). The greater AUC for WHtR in different population groups supports its use as a reliable screening tool for adiposity. Furthermore, the WHtR index overcomes some of the limitations of WC as it is adjusted for height. Because WHtR removes the height variation effect, it can be a determinant of body fat distribution. Moreover, $\mathrm{WHtR}$ does not need age- and sex-specific references and so it is easier to interpret. In our study, the optimal cut-off points of WHtR to define overweight and obesity were respectively 0.46 and 0.49 in male students and 0.47 and 0.50 in female students. Similar studies used WHtR thresholds to identify adiposity in children, also showing nearly consistent results $(30,32,33)$.

We found a suitable area under the ROC curve for WC. The optimal accuracy of WC to detect overweight and excess fat was consistent with recent findings (30,33,35-37). WC is known to be a practical tool for screening of overnutrition. Because of the appropriate accuracy and ease of measuring and interpreting WC, it can be used alone or with BMI to satisfactorily screen for overweight and obesity, and could overcome the BMI limitations. Fujita et al., using a DEXA technique, showed a direct relationship between body fat and BMI, WC and WHtR (30). WC has also been reported to be a more sensitive index for detecting body fat percentage compared with BMI (38), and can predict cardio/metabolic disorders and metabolic syndrome conditions $(39,40)$.

We estimated that the optimal cut-off points of WC were $73 \mathrm{~cm}$ to identify overweight and $77 \mathrm{~cm}$ for 


\begin{tabular}{|c|c|c|c|c|c|}
\hline Anthropometric parameter & Underweight & Normal weight & Overweight & Obesity & P-value \\
\hline Waist circumference $(\mathrm{cm})$ & $61.91(6.72)$ & $68.72(8.95)$ & $78.38(10.27)$ & $87.90(11.51)$ & $<0.001^{\mathrm{a}}$ \\
\hline Waist-to-hip ratio & $0.83(0.07)$ & $0.83(0.07)$ & $0.85(0.07)$ & $0.88(0.07)$ & $<0.001^{\mathrm{b}}$ \\
\hline Waist-to-height ratio & $0.40(0.04)$ & $0.44(0.05)$ & $0.45(0.06)$ & $0.55(0.06)$ & $<0.001^{\mathrm{a}}$ \\
\hline Neck circumference $(\mathrm{cm})$ & $28.07(1.84)$ & $30.14(2.25)$ & $32.42(2.49)$ & $34.27(2.57)$ & $<0.001^{a}$ \\
\hline
\end{tabular}

Data are presented as mean (standard deviation).

$P$-values were calculated by one way ANOVA.

aStatistically significant differences between all nutritional status subgroups (post-hoc test).

${ }^{b}$ Statistically significant differences between all nutritional status subgroups except underweight and normal subgroups (post-hoc test).

Table 4 Area under the receiver operating characteristic curve of anthropometric indices to determine overweight and obesity, based on body mass index level, in Iranian students aged 12-14 years

\begin{tabular}{|c|c|c|c|c|c|c|c|}
\hline \multicolumn{2}{|c|}{ Anthropometric indices } & \multicolumn{3}{|c|}{ Overweight } & \multicolumn{3}{|c|}{ Obesity } \\
\hline & & Girls & Boys & Total & Girls & Boys & Total \\
\hline \multirow[t]{2}{*}{ Waist circumference } & AUC & 0.83 & 0.87 & 0.85 & 0.85 & 0.91 & 0.88 \\
\hline & $95 \% \mathrm{CI}$ & $0.80-0.86$ & $0.84-0.89$ & $0.83-0.87$ & $0.81-0.90$ & $0.87-0.95$ & $0.86-0.91$ \\
\hline \multirow[t]{2}{*}{ Waist-to-hip ratio } & AUC & 0.62 & 0.67 & 0.64 & 0.63 & 0.74 & 0.69 \\
\hline & $95 \% \mathrm{CI}$ & $0.59-0.66$ & $0.63-0.71$ & $0.61-0.66$ & $0.57-0.69$ & $0.69-0.79$ & $0.65-0.73$ \\
\hline \multirow[t]{2}{*}{ Waist-to-height ratio } & AUC & 0.85 & 0.87 & 0.86 & 0.87 & 0.91 & 0.89 \\
\hline & $95 \% \mathrm{CI}$ & $0.82-0.88$ & $0.85-0.90$ & $0.84-0.88$ & $0.83-0.91$ & $0.88-0.95$ & $0.87-0.92$ \\
\hline \multirow[t]{2}{*}{ Neck circumference } & AUC & 0.84 & 0.82 & 0.83 & 0.87 & 0.87 & 0.87 \\
\hline & $95 \% \mathrm{CI}$ & $0.82-0.86$ & $0.80-0.85$ & $0.81-0.85$ & $0.84-0.90$ & $0.83-0.90$ & $0.85-0.89$ \\
\hline
\end{tabular}

$A U C=$ area under curve; $\mathrm{CI}=$ confidence interval.

obesity, in both sexes. These values concur with recent studies which used BMI centiles as the reference (29,35). Mazıcıoğlu et al. determined overweight in 13-year-old Turkish children and reported WC cut-off points of 72.5 in males and 67.5 in females (35). On the other hand, based on percentage of body fat, WC cut-off points in other studies showed lower values; this might be because of the younger age groups and also different socioeconomic status of the sample which affected the health status of children (31,33).

The Kurdishethnic groupin ourstudyhad significantly higher WC, WHtR and WHpR values compared with other ethnic groups. The high prevalence of abdominal obesity in Kurdish adolescents supports the use of WC and/or WHtR in screening for over-nutrition. Although the BMI values were significantly higher in students of Arab ethnicity, the central obesity measures in the Arab group were similar to other ethnicities. Therefore, the use of BMI centiles may be more appropriate in those of Arab ethnicity together with WC.

The area under the ROC curve for WHpR was not in a suitable range. WHpR is a less accurate anthropometric measurement tool, especially in obese subjects, as it will underestimate the obesity and central body fat because both waist and hip circumferences increase similarly in overweight or obese people. Therefore, it may not be a useful predictive index of metabolic disease. In other studies, WHpR was also reported to be a less accurate index than WC and WHtR $(41,42)$.
In our study, NC showed an adequate accuracy to identify overweight and obesity. The AUC of NC was lower than WHtR and WC but higher than WHpR. In this regard, Coutinho et al. reported a direct relationship between NC and BMI, WC, and body fat\%. Hatipoglu et al. also reported NC to be an easy and accurate method to diagnose children with higher BMI levels $(41,43)$; however they concluded WC was superior to NC for identifying overweight and obesity (41). The optimal cut-off points for NC in our study were $30.9 \mathrm{~cm}$ and $31.6 \mathrm{~cm}$ for overweight and obesity respectively in both sexes. Hatipoglu et al. reported similar NC values of $32.5 \mathrm{~cm}$ (males) and 31 $\mathrm{cm}$ (females) in post-pubertal subjects (41). We observed significantly higher NC values in Kurdish and Turkish ethnic groups and significantly lower values in Arab and Sistani and Baluchi participants. This is in line with our results for the central adiposity indices that showed higher upper fat content in the Kurdish adolescents and relatively lower fat content in students of Arab ethnicity.

The main limitation of our study was the lack of body composition analysis and skinfold thickness values to measure adiposity. Furthermore, because we sampled just 5 ethnic groups, the overall prevalence of overweight and obesity and also the optimal cut-off points cannot be generalized to the Iranian student population. Therefore, in accordance with our objective, the results are presented separately by ethnic groups. Moreover, Fars ethnicity, which is a major ethnic group of the Islamic Republic of Iran, was not included in our study, although it would be an appropriate comparison group. 
Figure 2 Area under the receiver operating characteristic curves for waist circumference (WC), waist-to-hip ratio (WHpR), waist-to-height ratio (WHtR) and neck circumference (NC) to define overweight in females (A1) and males (A2), and obesity in females (B1) and males (B2)

\section{A1: Overweight/ Girls}

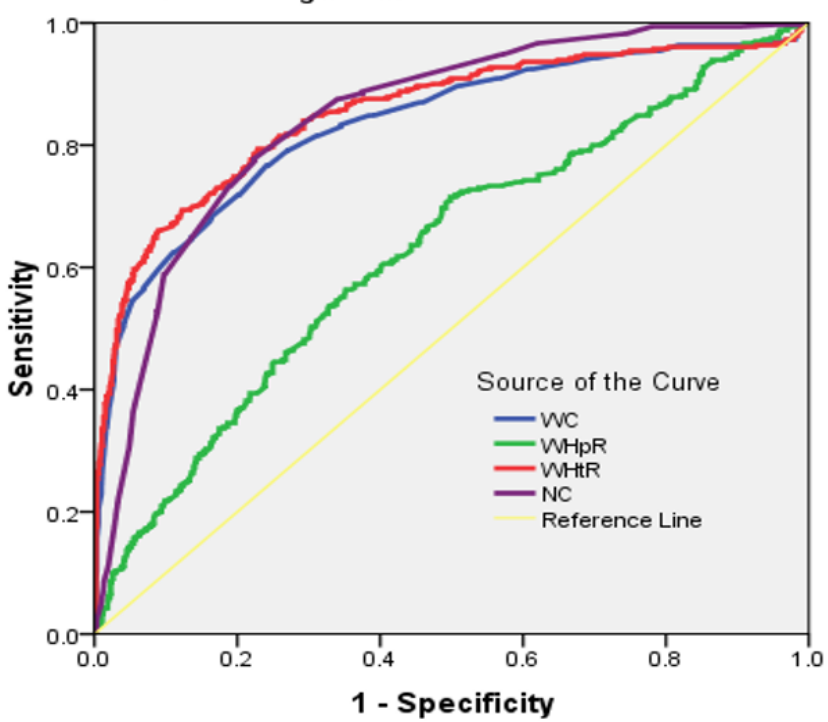

\section{A1: Overweight/ Girls}

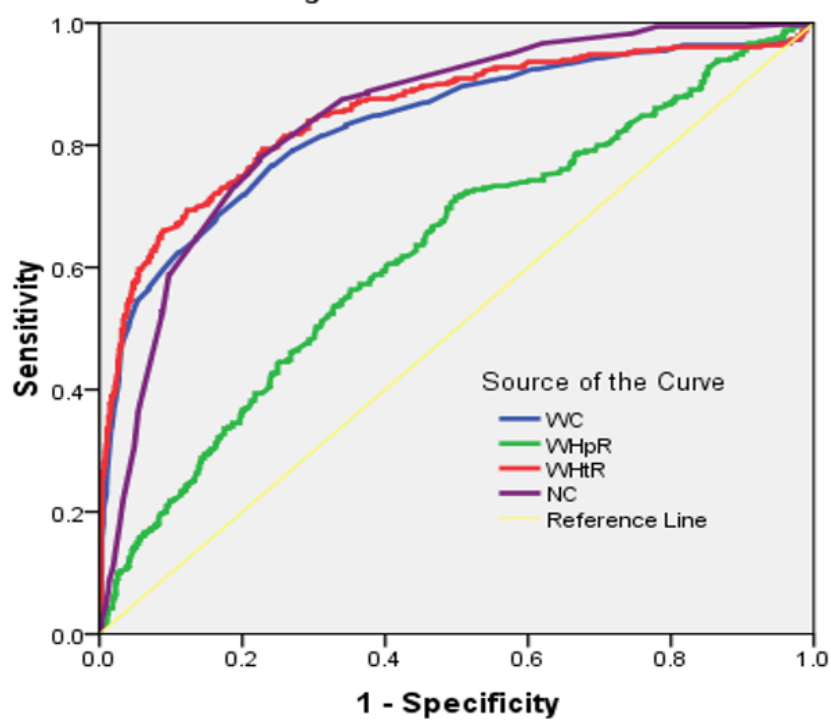

\section{A2: Overweight/ Boys}

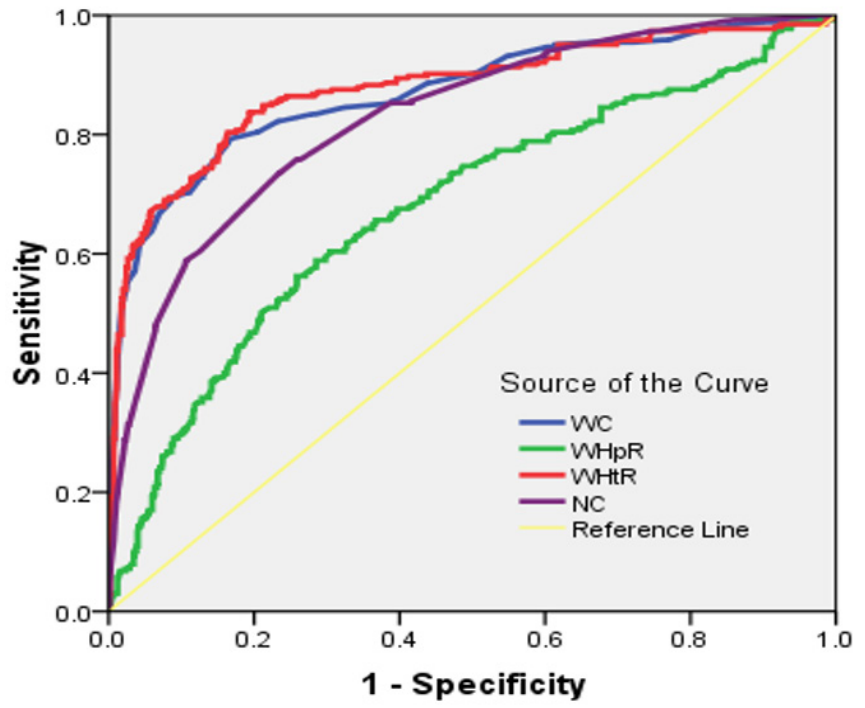

A2: Overweight/ Boys

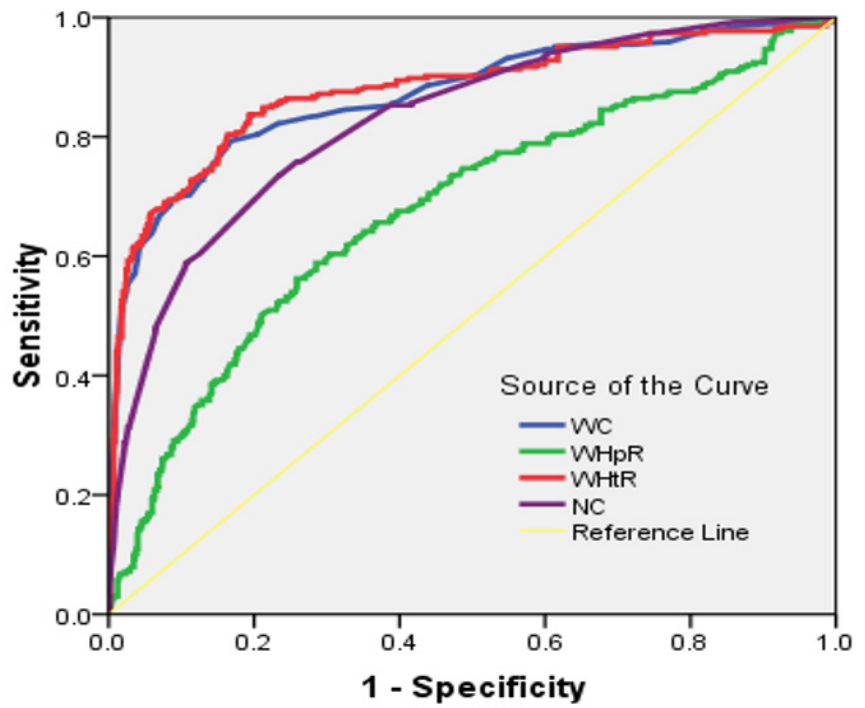




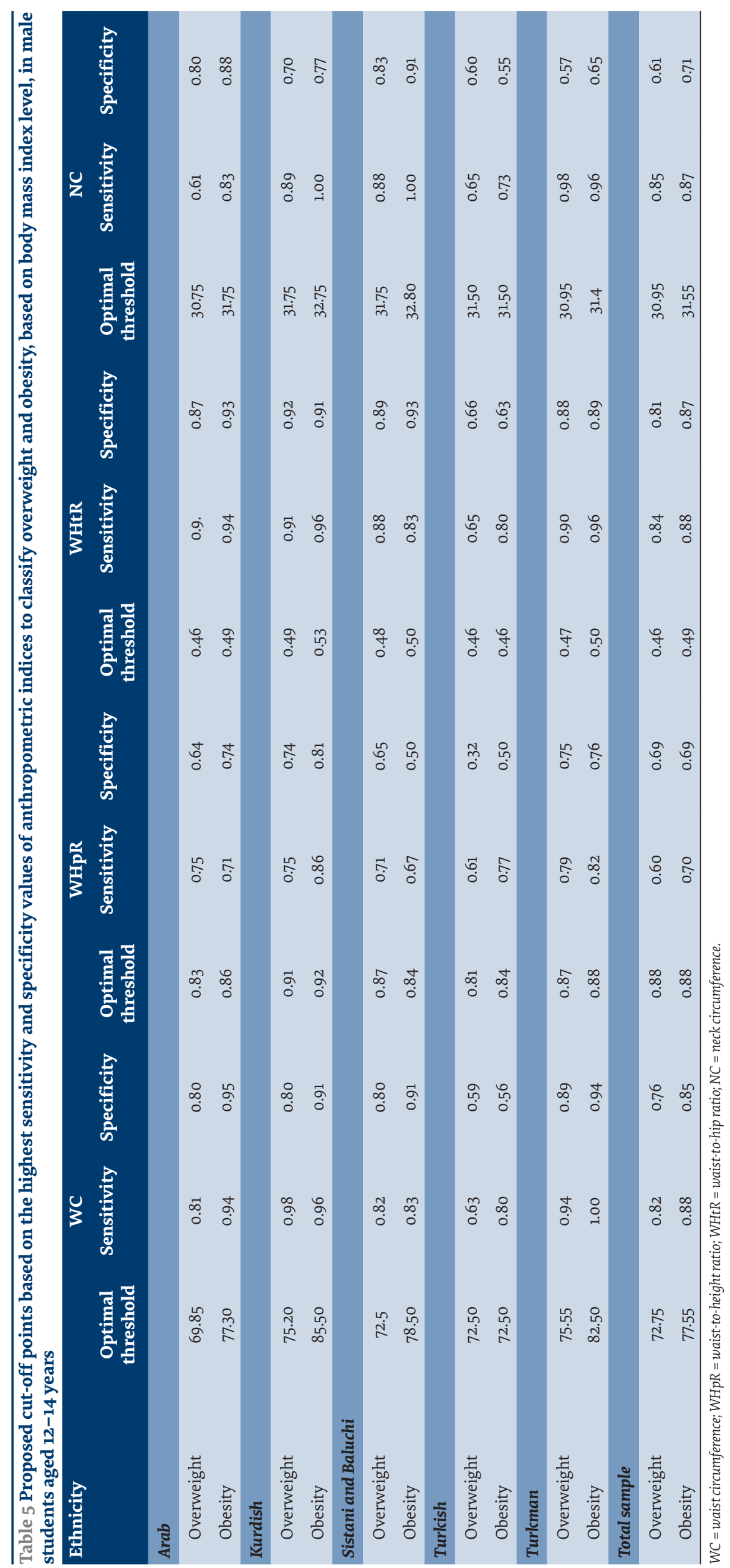




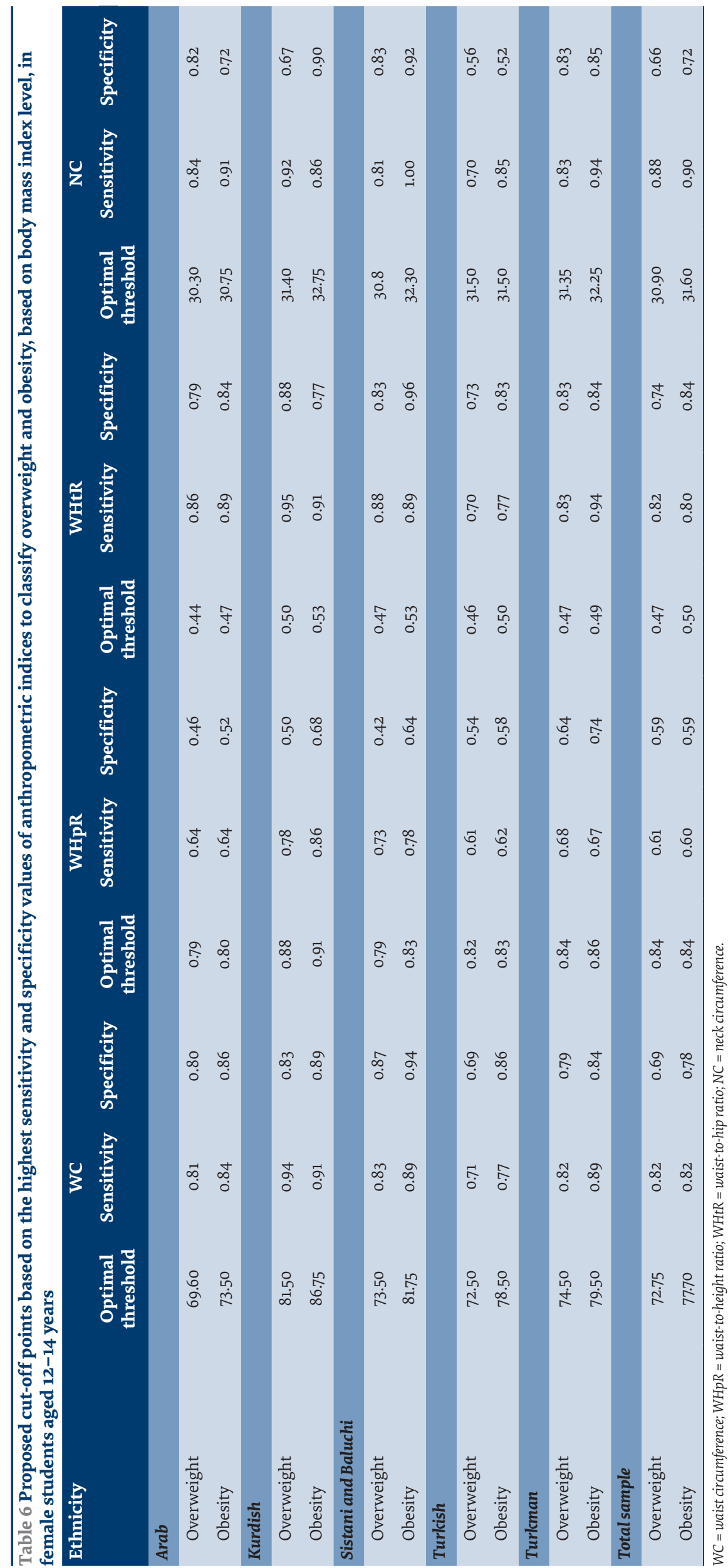




\section{Conclusion}

The prevalence of overweight and obesity is of concern and needs to be considered in health programmes. The rates were different in various ethnic groups. WC, WHtR and NC successfully identified overweight and obesity in Iranian adolescents. Ethnic differences need to be considered to estimate optimal cut-off points of anthropometric indices.

\section{Acknowledgements}

We thank the health services staff in all 5 provinces for conducting the interviews and collecting the data. We are also grateful to the parents and caregivers for consenting to their children's participation in the study.

Funding: This study was financially supported by Ahvaz Jundishapur University of Medical Science, Ahvaz, Islamic Republic of Iran (Registration no. AJUMS.REC.1393.119).

Competing interests: None declared.

\section{Évaluation de la surcharge pondérale et de l'obésité chez les adolescents iraniens : valeurs seuils optimales pour les indices anthropométriques}

\section{Résumé}

Contexte : Divers indices sont utilisés pour estimer la surcharge pondérale et l'obésité ; ils présentent tous des avantages et des inconvénients. La prévalence de la surcharge pondérale et de l'obésité peut varier en fonction de l'origine ethnique.

Objectifs : La présente étude a évalué le tour de taille, le rapport tour de taille/tour de hanches, le rapport tour de taille/ taille et la circonférence du cou en les considérant comme des alternatives fiables à l'indice de masse corporelle pour dépister la surcharge pondérale et l'obésité. Elle a ensuite déterminé leurs valeurs seuils optimales pour différents groupes ethniques.

Méthodes : L'étude a été réalisée en République islamique d'Iran entre novembre 2015 et février 2016 auprès d'adolescents âgés de 12 à 14 ans et issus de 5 groupes ethniques différents : arabe; kurde; sistani et baloutche; turc et turkmène. Une méthode d'échantillonnage stratifié à plusieurs degrés a été utilisée pour sélectionner 2444 étudiants. Des courbes ROC (fonction d'efficacité du récepteur) ont été tracées pour évaluer le tour de taille, le rapport tour de taille/tour de hanches, le rapport tour de taille/taille et la circonférence du cou en tant qu'indices de dépistage de la surcharge pondérale et de l'obésité telles que catégorisées par les percentiles d'indice de masse corporelle.

Résultats : La prévalence de la surcharge pondérale et de l'obésité dans l'échantillon total était, respectivement, de 15,3\% et 9,2\%. Des taux plus élevés ont été observés chez les étudiants d'origine arabe, kurde et turque. Les aires sous la courbe oscillaient entre 0,8 et 0,9 pour le tour de taille, le rapport tour de taille/taille et la circonférence du cou. Les valeurs optimales moyennes ayant la sensibilité et la spécificité la plus élevée pour dépister la surcharge pondérale étaient: $72,3 \mathrm{~cm}$ (sensibilité 0,80 ; spécificité 0,75$)$ pour le tour de taille, $0,46(0,85 ; 0,70)$ pour le rapport tour de taille/taille et $31 \mathrm{~cm}(0,76 ; 0,76)$ pour la circonférence du cou. Pour l'obésité, les valeurs optimales moyennes étaient : $77 \mathrm{~cm}(0,84 ; 0,81)$ pour le tour de taille, $0,50(0,84 ; 0,84)$ pour le rapport tour de taille/taille et $31,5 \mathrm{~cm}(0,88 ; 0,71)$ pour la circonférence du cou.

Conclusions : Les valeurs optimales du tour de taille, du rapport tour de taille/taille et de la circonférence du cou selon le sexe et le groupe ethnique peuvent s'avérer utiles pour dépister l'adiposité.

$$
\begin{aligned}
& \text { تقييم لزيادة الوزن و السمنة لدى المراهقين الإير انيين: القيم المثلى لقطع مؤشر ات الأنثروبومترية } \\
& \text { محمد مطلق، السيد شيرواني، زهر اء حسن زاده رستمي، مجذوبة طاهري، رضا قديمي } \\
& \text { الخالاصة } \\
& \text { الخلفية: استخدمت مختلف المناسب لتقدير زيادة الوزن و السمنة؛ وكان لجميعها مواطن قوة وضعف. ويختلف معدل انتشار زيادة الوزن و السمنة } \\
& \text { باختلاف العرق. } \\
& \text { الأهداف: قيمت هذه الدراسة استخدام محيط الخصر ونسبة الخصر إلى الورك ونسبة الخصر إلى الطول ومحيط الرقبة كبدائل موثوقة لمنْسَب كتلة }
\end{aligned}
$$

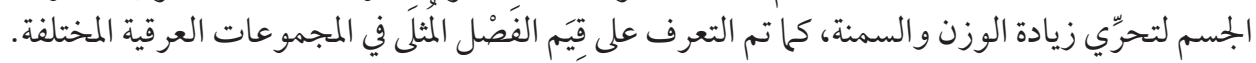

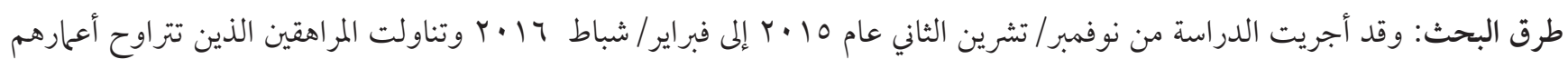

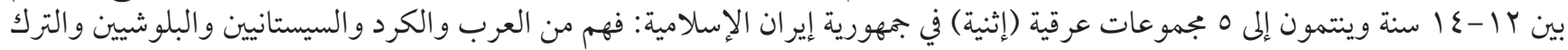

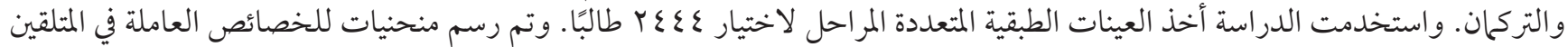

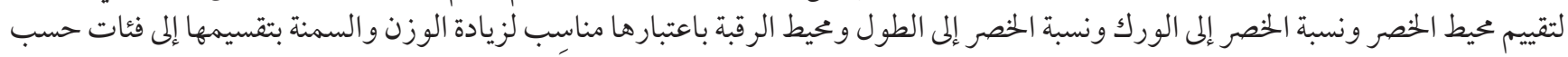


الشر ائح المئوية لمنْسَب كتلة الجمسم.

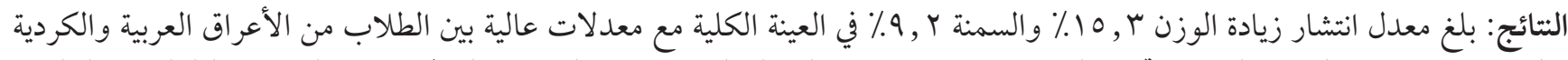

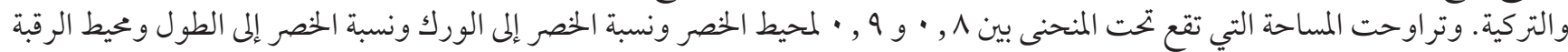

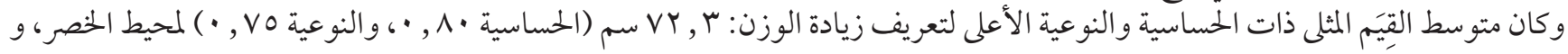

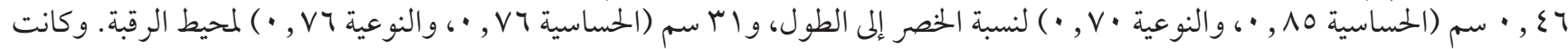

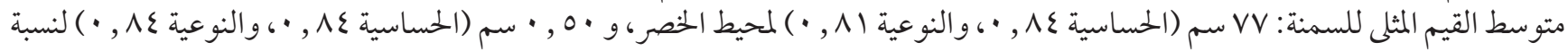

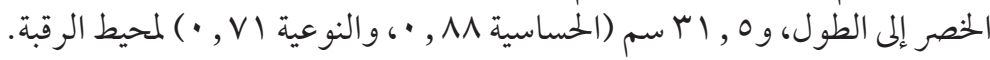

الاستنتاجات: محيط الخصر، ونسبة الخصر إلى الطول، ومحيط الرقبة قد تكون أدوات مفيدة لتحري السمنة واستخدام قيمها المثلى للجنس وللعرق.

\section{References}

1. Liang J, Wang Y, Dou L, Li H, Liu X, Qiu Q, et al. Neck circumference and prehypertension: the cardiometabolic risk in Chinese study. J Hypertens. 2015 Feb;33(2):275-8. https://doi.org/10.1097/HJH.0000000000000396 PMID:25545838

2. Onat A, Hergenc G, Yuksel H, Can G, Ayhan E, Kaya Z, et al. Neck circumference as a measure of central obesity: associations with metabolic syndrome and obstructive sleep apnea syndrome beyond waist circumference. Clin Nutr. 2009 Feb;28(1):46-51. https://doi.org/10.1016/j.clnu.2008.10.006 PMID:19010573.

3. Karpe F, Pinnick KE. Biology of upper-body and lower-body adipose tissue-link to whole-body phenotypes. Nat Rev Endocrinol. 2015 Feb;11(2):90-100. https://doi.org/10.1038/nrendo.2014.185 PMID:25365922

4. Oliveros E, Somers VK, Sochor O, Goel K, Lopez-Jimenez F. The concept of normal weight obesity. Prog Cardiovasc Dis. 2014 JanFeb;56(4):426-33. https://doi.org/10.1016/j.pcad.2013.10.003 PMID:24438734

5. Pawaskar PN, Shirali A, Prabhu MV, Pai SR, Kumar NA, Pawaskar NG. Comparing Utility of Anthropometric Indices Based on Gender Differences in Predicting Dyslipidaemia in Healthy Adults. J Clin Diagn Res. 2015 Aug;9(8):CCo1-04. PMID:26435939

6. Brambilla P, Bedogni G, Heo M, Pietrobelli A. Waist circumference-to-height ratio predicts adiposity better than body mass index in children and adolescents. Int J Obes (Lond). 2013 Jul;37(7):943-6. https://doi.org/10.1038/ijo.2013.32 PMID:23478429 6.

7. Ahanjideh F, Keshtkar AA, Payab M, Qorbani M, Shaygan N, Ramim T, et al. Relationship between abdominal obesity, body mass index, and history of fractures with bone density in the Iranian population: a national comprehensive plan for the prevention, diagnosis and treatment of osteoporosis. Iranian Journal Diabetes and Metabolism. 2016;14(3):217-24.

8. Stabe C, Vasques AC, Lima MM, Tambascia MA, Pareja JC, Yamanaka A, et al. Neck circumference as a simple tool for identifying the metabolic syndrome and insulin resistance: results from the Brazilian Metabolic Syndrome Study. Clin Endocrinol (Oxf). 2013 Jun;78(6):874-81. https://doi.org/10.1111/j.1365-2265.2012.04487.x PMID:22804918

9. Yang GR, Yuan SY, Fu HJ, Wan G, Zhu LX, Bu XL, et al.; Beijing Community Diabetes Study Group. Neck circumference positively related with central obesity, overweight, and metabolic syndrome in Chinese subjects with type 2 diabetes: Beijing Community Diabetes Study 4. Diabetes Care. 2010 Nov;33(11):2465-7. https://doi.org/10.2337/dc10-0798 PMID:20724650

10. Zen V, Fuchs FD, Wainstein MV, Gonçalves SC, Biavatti K, Riedner CE, et al. Neck circumference and central obesity are independent predictors of coronary artery disease in patients undergoing coronary angiography. Am J Cardiovasc Dis. 2012;2(4):32330. PMID:23173107

11. Leitzmann MF, Moore SC, Koster A, Harris TB, Park Y, Hollenbeck A, et al. Waist circumference as compared with body-mass index in predicting mortality from specific causes. PLoS One. 201104 26;6(4):e18582. https://doi.org/10.1371/journal.pone.0018582 PMID:21541313

12. Winter Y, Rohrmann S, Linseisen J, Lanczik O, Ringleb PA, Hebebrand J, et al. Contribution of obesity and abdominal fat mass to risk of stroke and transient ischemic attacks. Stroke. 2008 Dec;39(12):3145-51. https://doi.org/10.1161/STROKEAHA.108.523001 PMID:18703800

13. Ben-Noun LL, Laor A. Relationship between changes in neck circumference and changes in blood pressure. Am J Hypertens. 2004 May;17(5 Pt 1):409-14. https://doi.org/10.1016/j.amjhyper.2004.02.005 PMID:15110899

14. Duncan JS, Duncan EK, Schofield G. Accuracy of body mass index (BMI) thresholds for predicting excess body fat in girls from five ethnicities. Asia Pac J Clin Nutr. 2009;18(3):404-11. PMID:19786389

15. WHO Expert Consultation. Appropriate body-mass index for Asian populations and its implications for policy and intervention strategies. Lancet. 2004;363:157-63. https://doi.org/10.1016/S0140-6736(03)15268-3 PMID:14726171

16. Hoseini Seiyedi S, Malekzadeh Kebria R, Ashrafian Amiri H, Habibzadeh R, Aligoltabar M, Nasrollapour Shirvani S. Personal and behavioral factors affecting body mass index in first grade high school students of Babol, Iran. Journal of Babol University of Medical Sciences. 2016;18(3):69-75.

17. Kuczmarski RJ, Ogden CL, Guo SS, Grummer-Strawn LM, Flegal KM, Mei Z, et al. 2000 CDC growth charts for the United States: methods and development. Vital Health Stat 11. 2002; (246):1-190. PMID:12043359

18. Kelishadi R, Haghdoost AA, Sadeghirad B, Khajehkazemi R. Trend in the prevalence of obesity and overweight among Iranian children and adolescents: a systematic review and meta-analysis. Nutrition. 2014 Apr;30(4):393-400. https://doi.org/10.1016/j. 
nut.2013.08.011 PMID:24332523

19. Taheri F, Kazemi T, Chahkandi T, Namakin K, Zardast M, Bijari B. Prevalence of overweight, obesity and central obesity among elementary school children in Birjand, east of Iran, 2012. J Res Health Sci. 2013 09 17;13(2):157-61. PMID:24077473

20. Mirmohammadi SJ, Hafezi R, Mehrparvar AH, Rezaeian B, Akbari H. Prevalence of overweight and obesity among Iranian school children in different ethnicities. Iran J Pediatr. 2011 Dec;21(4):514-20. PMID:23056841

21. Jafari-Adli S, Jouyandeh Z, Qorbani M, Soroush A, Larijani B, Hasani-Ranjbar S. Prevalence of obesity and overweight in adults and children in Iran; a systematic review. J Diabetes Metab Disord. 201412 23;13(1):121. https://doi.org/10.1186/s40200-014-0121-2 PMID:25610814

22. Azizi F, Allahverdian S, Mirmiran P, Rahmani M, Mohammadi F. Dietary factors and body mass index in a group of Iranian adolescents: Tehran lipid and glucose study-2. Int J Vitam Nutr Res. 2001 Mar;71(2):123-7. https://doi.org/10.1024/0300-9831.71.2.123 PMID:11339109

23. Kelishadi R, Ardalan G, Qorbani M, Ataie-Jafari A, Bahreynian M, Taslimi M, et al. Methodology and early findings of the fourth survey of childhood and adolescence surveillance and prevention of adult non-communicable disease in Iran: The CASPIAN-IV study. Int J Prev Med. 2013 Dec;4(12):1451-60. PMID:24498502

24. Popkin BM, Adair LS, Ng SW. Global nutrition transition and the pandemic of obesity in developing countries. Nutr Rev. 2012 Jan;70(1):3-21. https://doi.org/10.1111/j.1753-4887.2011.00456.x PMID:22221213

25. Abuyassin B, Laher I. Obesity-linked diabetes in the Arab world: a review. East Mediterr Health J. 2015 09 8;21(6):420-39. https:// doi.org/10.26719/2015.21.420 PMID:26370001

26. Hajian-Tilaki K, Heidari B. Prevalences of overweight and obesity and their association with physical activity pattern among Iranian adolescents aged 12-17 years. Public Health Nutr. 2012 Dec;15(12):2246-52. https://doi.org/10.1017/S1368980012001048 PMID:22578771

27. Musaiger AO. Overweight and obesity in Eastern Mediterranean Region: prevalence and possible causes. J Obes. 2011;2011:407237. https://doi.org/10.1155/2011/407237 PMID:21941635.

28. Hajian-Tilaki KO, Sajjadi P, Razavi A. Prevalence of overweight and obesity and associated risk factors in urban primary-school children in Babol, Islamic Republic of Iran. East Mediterr Health J. 2011 Feb;17(2):109-14. PMID:21735944

29. Brannsether B, Roelants M, Bjerknes R, Juliusson PB. Waist circumference and waist-to-height ratio in Norwegian children 4-18 years of age: reference values and cut-off levels. Acta Paediatr. 2011 Dec;10o(12):1576-82. https://doi.org/10.1111/j.16512227.2011.02370.x PMID:21627692.

30. Fujita Y, Kouda K, Nakamura H, Iki M. Cut-off values of body mass index, waist circumference, and waist-to-height ratio to identify excess abdominal fat: population-based screening of Japanese school children. J Epidemiol. 2011;21(3):191-6. https://doi. org/10.2188/jea.JE20100116 PMID:21467729

31. Rerksuppaphol S, Rerksuppaphol L. Optimal cut-off points of weight for height, waist circumference and waist-to-height ratio for defining overweight and obesity in Thai school-aged children. J Res Health Sci. 2013 05 29;13(1):13-8. PMID:23772011

32. Nambiar S, Hughes I, Davies PS. Developing waist-to-height ratio cut-offs to define overweight and obesity in children and adolescents. Public Health Nutr. 2010 Oct;13(10):1566-74. https://doi.org/10.1017/S1368980009993053 PMID:20100388

33. Hubert H, Guinhouya CB, Allard L, Durocher A. Comparison of the diagnostic quality of body mass index, waist circumference and waist-to-height ratio in screening skinfold-determined obesity among children. J Sci Med Sport. 2009 Jul;12(4):449-51. https://doi.org/10.1016/j.jsams.2008.05.002 PMID:18768363

34. Ashwell M, Gunn P, Gibson S. Waist-to-height ratio is a better screening tool than waist circumference and BMI for adult cardiometabolic risk factors: systematic review and meta-analysis. Obes Rev. 2012 Mar;13(3):275-86. https://doi.org/10.1111/j.1467789X.2011.00952.x PMID:22106927

35. Mazıcıoğlu MM, Hatipoğlu N, Oztürk A, Ciçek B, Ustünbaş HB, Kurtoğlu S. Waist circumference and mid-upper arm circumference in evaluation of obesity in children aged between 6 and 17 years. J Clin Res Pediatr Endocrinol. 2010;2(4):144-50. https://doi. org/10.4274/jcrpe.v2i4.144 PMID:21274313

36. Reilly JJ, Dorosty AR, Ghomizadeh NM, Sherriff A, Wells JC, Ness AR. Comparison of waist circumference percentiles versus body mass index percentiles for diagnosis of obesity in a large cohort of children. Int J Pediatr Obes. 2010 Apr;5(2):151-6. https:// doi.org/10.3109/17477160903159440 PMID:19657861.

37. Glässer N, Zellner K, Kromeyer-Hauschild K. Validity of body mass index and waist circumference to detect excess fat mass in children aged 7-14 years. Eur J Clin Nutr. 2011 Feb;65(2):151-9. https://doi.org/10.1038/ejcn.2010.245 PMID:21048772

38. Hosseini M, Amirkhani MA, Mansourian M, Ziaoddini H, Ardalan G, Poursafa P, et al. Risk scoring system for prediction of abdominal obesity in a national sample of youths: CASPIAN Study. ARYA Atherosclerosis J. 2009;5(2):85-8.

39. Maffeis C, Banzato C, Talamini G; Obesity Study Group of the Italian Society of Pediatric Endocrinology and Diabetology. Waistto-height ratio, a useful index to identify high metabolic risk in overweight children. J Pediatr. 2008 Feb;152(2):207-13. https://doi. org/10.1016/j.jpeds.2007.09.021 PMID:18206690

40. Chen B, Li HF. Waist circumference as an indicator of high blood pressure in preschool obese children. Asia Pac J Clin Nutr. 2011;20(4):557-62. PMID:22094841 
41. Hatipoglu N, Mazicioglu MM, Kurtoglu S, Kendirci M. Neck circumference: an additional tool of screening overweight and obesity in childhood. Eur J Pediatr. 2010 Jun;169(6):733-9. https://doi.org/10.1007/s00431-009-1104-z PMID:19936785

42. Mushtaq MUGS, Gull S, Abdullah HM, Shahid U, Shad MA, Akram J. Waist circumference, waist-hip ratio and waist-height ratio percentiles and central obesity among Pakistani children aged five to twelve years. BMC Pediatr. 2011 11 21;11(1):105. https://doi. org/10.1186/1471-2431-11-105 PMID:22104025

43. Coutinho CA, Longui CA, Monte O, Conde W, Kochi C. Measurement of neck circumference and its correlation with body composition in a sample of students in São Paulo, Brazil. Horm Res Paediatr. 2014;82(3):179-86. https://doi.org/10.1159/000364823 PMID:25138376 